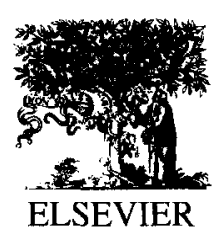

Marine Micropaleontology 31 (1997) 135-155

\title{
Benthic foraminiferal ecomarker species of the terminal Cretaceous (late Maastrichtian) deep-sea Tethys
}

\author{
Joen G.V. Widmark ${ }^{*}, \equiv$ ert P. Speijer ${ }^{1}$ \\ Göteborg University, Department of Earth Sciences, Marine Geology, 41381 Göteborg. Sweden
}

Received 6 April 1996: accepted 2 January 1997

\begin{abstract}
Benthic foraminiferal distribution patterns throughout the late Maastrichtian Tethyan deep sea are analyzed. Many species are ubiquitously distributed throughout this region and therefore it is hard to assess their ecological preferences. However, five species show distribution patterns, which suggest that they may have distinctive paleoenvironmental preferences. These preferences are interpreted from hypothesized surface circulation and upwelling patterns. Additional information comes from Recent benthic foraminiferal ecology and from responses to the Cretaceous/Paleogene $(\mathrm{K} / \mathrm{Pg})$ boundary event. This enables us to assess the ecological preferences of these late Maastrichtian taxa, and establish them as ecological-marker (ecomarker) species for paleoenvironmental interpretation of the late Maastrichtian bathyal-abyssal Tethyan realm.

(1) Eouvigerina subsculptura is suggested to be indicative of reasonably oxygenated upper-middle bathyal environments, though with high abundance of utilizable organic matter. (2) Sliteria varsoviensis is linked to areas of late Maastrichtian upwelling and seems to have been an epibenthic species with an opportunistic life mode. (3) Gavelinella beccariiformis and (4) Nuttallides truempyi are considered to be indicative of oligotrophic conditions unless they occur with a large proportion of endobenthic morphotypes. (5) Gavelinella pertusa is proposed to indicate neritic-middle bathyal environments of the 'boreal' realm, which might be influenced by more seasonal food-fluxes and by higher oxygen levels than similar settings in the (sub)tropics.

Finally, the anomalous high abundances of the buliminid species Sitella cf. plana in deep open ocean environments is discussed in terms of possible mechanisms permitting such a (morphologically) opportunistic species to thrive in such an assumedly oligotrophic environment.
\end{abstract}

Keywords: Late Cretaceous; Maastrichtian; benthic foraminifera; paleoecology; paleoenvironment; paleobathymetry; paleolatitude; paleocirculation; food fluxes; trophic level; oxygenation

\section{Introduction}

The two primary ecological parameters controlling the distribution and density of benthic forami-

\footnotetext{
*Corresponding author. Fax: $+46 \quad 31$ 773-4903. E-mail: joen@gvc.gu.se

${ }^{1}$ Present address: FB5 Geosciences, Bremen University, Box 330440, 28334 Bremen, Germany.
}

niferal species are trophic level (food availability) and oxygenation at, and within, the seabed. There is, however, disagreement on which of these interrelated parameters has the largest impact on benthic foraminiferal community structure (e.g., Gooday, 1986; Corliss and Chen, 1988; Mackensen and Douglas, 1989; Corliss and Emerson, 1990; Corliss, 1991; Barmawidjaja et al., 1992; Rosoff and Corliss, 1992; Sjoerdsma and Van der Zwaan, 1992; Jorissen et 